DOI: $10.19195 / 0137-1134.116 .8$

\author{
ROBERT TALAGA
}

ORCID: 0000-0002-5281-2188

Wojewódzki Sąd Administracyjny w Poznaniu

\title{
REPREZENTACJA NIEZNANYCH SPADKOBIERCÓW PRZED SĄDEM ADMINISTRACYJNYM - WYBRANE ZAGADNIENIA PRAWA POMOCY
}

\begin{abstract}
Abstrakt: W miejsce strony postępowania przed sądem administracyjnym może wstąpić ustanowiony kurator spadku. Taki podmiot jest ustanawiany przez sąd spadku i sprawuje swoją funkcję do momentu objęcia masy spadkowej przez spadkobierców. Przyjęcie jednej z funkcjonujących w literaturze i orzecznictwie koncepcji dotyczących reprezentacji nieznanych spadkobierców ma kluczowe znaczenie dla wszystkich podmiotów obrotu gospodarczego. Warunkuje ona bowiem konsekwencje podejmowanych przez kuratora spadku czynności prawnych (materialnych oraz procesowych) względem spadkobierców. W postępowaniu prowadzonym przed sądem administracyjnym w szczególności dotyczy to możliwości ubiegania się o przyznanie prawa pomocy, a więc wpływa na realizację konstytucyjnego prawa do sądu.
\end{abstract}

Słowa kluczowe: kurator spadku, prawo pomocy, postępowanie przed sądem administracyjnym, koszty sądowe

\section{WPROWADZENIE}

Każda strona postępowania sądowoadministracyjnego jest uprawniona do podejmowania $\mathrm{w}$ granicach prawa czynności procesowych mających na celu jak najlepszą reprezentację swoich interesów. W tym względzie przysługuje im również prawo ubiegania się o przyznanie prawa pomocy, czyli o zwolnienie od kosztów sądowych i ustanowienie profesjonalnego pełnomocnika $z$ urzędu finansowanego ze środków publicznych ${ }^{1}$. W przypadku śmierci osoby fizycznej ubiegającej się o prawo pomocy w trakcie postępowania mamy do czynienia z sytuacją szczególną. Bezprzedmiotowe staje się wówczas kontynuowanie postępowania w przedmiocie przyznania prawa pomocy. Niedopuszczalne jest bowiem merytoryczne orzekanie w przedmiocie przyznania bądź odmowy przyznania prawa pomocy osobie

1 Zob. art. 243 ustawy z dnia 30 sierpnia 2002 roku Prawo o postępowaniu przed sądami administracyjnymi (tekst jedn. Dz.U. z 2018 r. poz. 1302 ze zm., dalej: P.p.s.a.). 
nieżyjącej². Takiej wątpliwości nie ma również w przypadku zgonu osoby, która uprzednio uzyskała prawo pomocy, gdyż owo uprawnienie wygasa z chwilą śmierci podmiotu, któremu zostało ono przyznane (art. 251 P.p.s.a.). W obu przypadkach wspomniane konsekwencje są pochodną osobistego charakteru prawa pomocy, które jest przyznawane na podstawie oceny indywidualnej sytuacji materialnej i osobistej wnioskodawcy. Zgodnie z przyjętą w polskim prawie konstrukcją dziedziczenia to spadkobiercy są podmiotem praw i obowiązków majątkowych wchodzących w skład nieobjętego spadku³. Jeżeli spadkobiercy nie są znani, ich interesy może reprezentować kurator spadku ustanowiony przez sąd spadku. Wówczas prawo pomocy uprzednio przyznane stronie, która następnie zmarła, nie wpływa na sytuację prawną podmiotów wstępujących w miejsce zmarłej strony do postępowania sądowego ${ }^{5}$. Kurator spadku nie może zatem skorzystać z prawa pomocy, jakie zostało uprzednio przyznane spadkodawcy będącemu stroną prowadzonego postępowania sądowoadministracyjnego. Istotną kwestią pozostaje wówczas dopuszczalność ubiegania się przez kuratora spadku o przyznanie prawa pomocy.

Niniejsze opracowanie ma na celu analizę możliwości skorzystania w trakcie prowadzonego postępowania przed sądem administracyjnym z instytucji prawa pomocy przez reprezentanta nieznanych spadkobierców (kuratora spadku). W tym względzie istotny pozostaje charakter prawny tego rodzaju kurateli oraz zakres przyznanego umocowania do podejmowania czynności w ramach sprawowanej funkcji. Oprócz obowiązujących przepisów prawnych konieczne pozostaje również uwzględnienie poglądów zaprezentowanych w dotychczasowym dorobku sądów powszechnych i sądów administracyjnych, a także konstrukcji jurydycznych prezentowanych w literaturze. Dopiero w ten sposób możliwe jest pełne ujęcie złożonej natury poruszanego zagadnienia, które może rodzić wątpliwości zarówno teoretyczne, jak i praktyczne.

2 Postanowienie referendarza sądowego WSA w Opolu z dnia 20 maja 2009 roku, sygn. akt II SA/Op 70/09, LEX nr 635211.

3 J.S. Piątowski, [w:] System prawa cywilnego, t. 4. Prawo spadkowe, red. J.S. Piątowski, Wrocław 1986, s. 116.

${ }^{4}$ Kurator spadku jest reprezentantem nieznanych spadkobierców nieobjętego spadku, a nie jak dawniej reprezentantem masy spadkowej — por. K. Korzan, Kurator w postępowaniu cywilnym, Warszawa 1966, s. 28; K. Korzan, Koszty procesu z udziałem kuratora, „Palestra” 1968, nr 2, s. 29.

5 Niezwrócenie się w trybie art. 128 § 2 P.p.s.a. do sądu spadku o ustanowienie kuratora spadku po wyczerpaniu przez sąd administracyjny czynności zmierzających do ustalenia kręgu następców prawnych zmarłej strony lub uczestnika postępowania we własnym zakresie naraża sąd administracyjny na usprawiedliwiony zarzut przewlekłości postępowania w rozumieniu przepisów ustawy z dnia 17 czerwca 2004 roku o skardze na naruszenie prawa strony do rozpoznania sprawy w postępowaniu przygotowawczym prowadzonym lub nadzorowanym przez prokuratora i postępowaniu sądowym bez nieuzasadnionej zwłoki (Dz.U. Nr 179, poz. 1843 ze zm.) - por. postanowienie NSA z dnia 9 października 2009 roku, sygn. akt I OPP 52/09, Orzecznictwo Naczelnego Sądu Administracyjnego i Wojewódzkich Sądów Administracyjnych 2010, nr 6, poz. 101, Orzecznictwo Sądów Polskich 2010, nr 7, poz. 72, LEX nr 653395. 


\section{ZAKRES WNIOSKU KURATORA SPADKU O PRZYZNANIE PRAWA} POMOCY

W literaturze ${ }^{6}$ najczęściej prezentowany jest pogląd, że ustanowiony przez sąd powszechny kurator spadku pozostaje z mocy art. $239 \S 1$ pkt 3 P.p.s.a. ustawowo zwolniony z obowiązku ponoszenia kosztów sądowych. Przyjęcie takiego stanowiska powoduje, że rozpoznanie złożonego przez kuratora spadku wniosku o przyznanie prawa pomocy w zakresie zwolnienia od kosztów sądowych jest zbędne i skutkuje umorzeniem zainicjowanego postępowania ${ }^{7}$. Ukształtowana w tym względzie praktyka orzecznicza sądów administracyjnych jest w główniej mierze oparta na „,daleko idących podobieństwach regulacji dotyczących kurateli, a w szczególności podobieństwie charakteru instytucji kurateli" umożliwiających objęcie kuratora spadku zwolnieniem podmiotowym od kosztów sądowych tak samo jak kuratorów wyznaczonych przez orzekający sąd administracyjny lub sąd opiekuńczy dla danej sprawy ${ }^{8}$. Takie stanowisko niewątpliwie nawiązuje do rozwiązania prawnego, jakie funkcjonowało już wcześniej w polskim systemie prawnym 9 .

${ }^{6}$ M. Jagielska, J. Jagielski, P. Gołaszewski, [w:] Prawo o postępowaniu przed sądami administracyjnymi. Komentarz, red. R. Hauser, M. Wierzbowski, Warszawa 2013, s. 849; M. Grzymisławska-Cybulska, Prawo pomocy w postępowaniu sqdowoadministracyjnym jako element realizacji prawa do sądu, Warszawa 2013, s. 72; L. Błystak, M. Kazek, Koszty postępowania sądowoadministracyjnego. Komentarz, Warszawa 2015, s. 169; M. Margoński, Kurator spadku, Warszawa 2009, s. 190.

7 Postanowienie referendarza sądowego WSA w Warszawie z dnia 18 listopada 2015 roku, sygn. akt I SA/Wa 1893/15, LEX nr 1961491; postanowienie referendarza sądowego WSA w Krakowie z dnia 4 grudnia 2015 roku, sygn. akt II SA/Kr 1357/15, LEX nr 1939285.

8 Postanowienia NSA z dnia: 17 marca 2010 roku, sygn. akt I OZ 187/10, LEX nr 606389; 18 lutego 2015 roku, sygn. akt I OZ 112/15, LEX nr 1772012; 20 stycznia 2015 roku, sygn. akt II OZ 8/15, LEX nr 1628856; 23 kwietnia 2015 roku, sygn. akt II OZ 336/15, LEX nr 1956722; wyrok WSA w Warszawie z dnia 7 listopada 2013 roku, sygn. akt VIII SA/Wa 564/13, LEX nr 1412272; postanowienia WSA w Gdańsku z dnia: 18 marca 2015 roku, sygn. akt II SA/Gd 479/14, LEX nr 1655034; 28 maja 2015 roku, sygn. akt II SA/Gd 479/14, LEX nr 1760132; postanowienie referendarza sądowego WSA w Krakowie z dnia 19 listopada 2010 roku, sygn. akt III SA/Kr 88/10, LEX nr 776457; postanowienie referendarza sądowego WSA w Warszawie z dnia 15 stycznia 2013 roku, sygn. akt I SA/Wa 1234/12, LEX nr 1283290; postanowienie referendarza sądowego WSA w Warszawie z dnia 18 lutego 2014 roku, sygn. akt I SA/Wa 18/14, LEX nr 1579195; postanowienie referendarza sądowego WSA w Warszawie z dnia 18 listopada 2014 roku, sygn. akt VII SA/Wa 2669/13, LEX nr 1594899; postanowienie referendarza sądowego WSA w Krakowie z dnia 16 stycznia 2015 roku, sygn. akt III SA/Kr 1183/14, LEX nr 1625613; postanowienie referendarza sądowego WSA w Gdańsku z dnia 11 sierpnia 2015 roku, sygn. akt III SA/Gd 1027/14, LEX nr 1776869; postanowienie referendarza sądowego WSA w Warszawie z dnia 18 listopada 2015 roku, sygn. akt I SA/Wa 1893/15, LEX nr 1961491; postanowienie referendarza sądowego WSA w Krakowie z dnia 4 grudnia 2015 roku, sygn. akt II SA/Kr 1357/15, LEX nr 1939285; postanowienie referendarza sądowego WSA w Gdańsku z dnia 30 czerwca 2017 roku, sygn. akt II SA/Gd 124/17, LEX nr 2311408.

9 Zgodnie z art. 79 ustawy z dnia 30 grudnia 1950 roku Przepisy o kosztach sądowych w sprawach cywilnych (tekst jedn. Dz.U. z 1961 r. Nr 10, poz. 57 ze zm.) kurator spadku był zwolniony od opłat sądowych. Takie rozwiązanie obowiązywało do momentu wejścia w życie ustawy z dnia 
Jednocześnie funkcjonują również inne poglądy ${ }^{10}$, zgodnie z którymi kurator spadku nie jest ustawowo zwolniony od obowiązku ponoszenia kosztów sądowych, gdyż nie wynika to bezpośrednio z treści obowiązujących przepisów, których nie można interpretować w sposób rozszerzający. Jednocześnie należy też pamiętać, że kurator spadku nie ma obowiązku osobistego ponoszenia kosztów sądowych, które co do zasady powinny być pokryte z zarządzanego majątku spadkowego ${ }^{11}$. Może się jednak zdarzyć, że nie ma możliwości pokrycia kosztów sądowych ze środków pochodzących ze spadku bądź z zarządzanego majątku spadkowego. W efekcie nie wyklucza to możliwości ubiegania się przez kuratora spadku o przyznanie prawa pomocy w zakresie zwolnienia od kosztów sądowych na zasadach ogólnych postępowania sądowoadministracyjnego ${ }^{12}$.

Rozstrzygnięcie kwestii dopuszczalności ubiegania się o przyznanie prawa pomocy przez kuratora spadku w zakresie zwolnienia od kosztów sądowych oznacza, że może on ubiegać się o przyznanie prawa pomocy w zakresie częściowym, a także w zakresie całkowitym. Niesporne pozostaje bowiem, że kurator spadku może ubiegać się o przyznanie prawa pomocy w zakresie ustanowienia z urzędu profesjonalnego pełnomocnika ${ }^{13}$. Szczególnym przypadkiem jest jednak sytuacja, w której sąd powszechny ustanawia kuratora spadku, który jednocześnie pozostaje profesjonalnym pełnomocnikiem, co podaje $\mathrm{w}$ wątpliwość uprawnienie takiego kuratora spadku do ubiegania się o przyznanie prawa pomocy w zakresie ustanowienia profesjonalnego pełnomocnika $z$ urzędu. W praktyce może on bowiem sam podjąć czynności prawne niezbędne do zapewnienia należytej profesjonalnej ochrony prawnej (na przykład sporządzić skargę kasacyjną lub zażalenie). Kurator spadku, który pozostaje profesjonalnym pełnomocnikiem procesowym (na przykład radcą prawnym, adwokatem, doradcą podatkowym itp.), może zatem bez dodatkowej pomocy podejmować czynności, które wymagają kwalifikacji

13 czerwca 1967 roku o kosztach sądowych w sprawach cywilnych (tekst jedn. Dz.U. z 2002 r. Nr 9 , poz. 88). Ustawowe zwolnienie kuratora spadku od kosztów sądowych w pewnym okresie stanowiło jednak tylko odstępstwo od wcześniejszej konstrukcji prawnej i poglądów funkcjonujących w literaturze - por. H. Behrman, Jakiej kategorii kuratorów przystuguje uwolnienie od kosztów sądowych na zasadzie art. 3 p.2 przep. o koszt. sadowych?, „Nowy Proces Cywilny” 1933, nr 13, s 411-413.

${ }^{10}$ M. Kowalczuk-Szymańska, Brak zwolnienia kuratora spadku od kosztów sądowych, „Monitor Prawniczy” 2010, nr 23 (bezpłatny dodatek), s. 16; T.M. Niemiec, Kurator spadku - zwolnienie z kosztów sq̨dowych, „Monitor Prawniczy” 2011, nr 22, s. 1234-1236; R. Talaga, Obowiązek ponoszenia kosztów sądowych przez kuratora spadku w postępowaniu przed sądami administracyjnymi, „Przegląd Sądowy” 2018, nr 4, s. 87-95.

11 K. Korzan, Koszty postępowania cywilnego a nakłady państwa na utrzymanie wymiaru sprawiedliwości, Gdańsk 1992, s. 145.

12 W postępowaniu cywilnym od dnia 20 czerwca 1967 roku kurator spadku został zobowiązany do ponoszenia pełnych kosztów sądowych tak jak wszystkie strony postępowania cywilnego, co oznaczało, że mógł je pokryć z majątku spadkowego albo ubiegać się o zwolnienie od kosztów na zasadach ogólnych — por. K. Korzan, Koszty procesu..., s. 24.

13 Postanowienie referendarza sądowego WSA w Gdańsku z dnia 30 czerwca 2017 roku, sygn. akt II SA/Gd 124/17. 
profesjonalnego pełnomocnika. Z uwagi na posiadane jednocześnie uprawnienia zawodowe (przynależność do korporacji profesjonalnych pełnomocników) kurator spadku nie może być jednak automatycznie traktowany jako pełnomocnik procesowy ustanowiony w ramach prawa pomocy (art. 244 § 2 P.p.s.a.).

Nieistnienie szczególnych regulacji dotyczących składania wniosku o przyznanie prawa pomocy przez kuratora spadku nie powinno być też traktowane jako przeszkoda ograniczająca prawo do sądu jednostkom (w tym przypadku nieznanym spadkobiercom strony postępowania) ${ }^{14}$. Wobec braku regulacji prawnych wykluczających zastosowanie takiego rozwiązania można zatem uznać je za dopuszczalne zgodnie z zasadą, że wszystko, co nie jest zabronione, jest dozwolone (quod lege non prohibitum licitum est). Potwierdzenie takiego uprawnienia kuratora spadku do ubiegania się o przyznanie prawa pomocy w zakresie zwolnienia od kosztów sądowych znajduje również swoje potwierdzenie w praktyce z uwagi na zapewnienie realizacji prawa do sądu ${ }^{15}$.

\section{SZCZEGÓLNY CHARAKTER KURATORA SPADKU W POSTĘPOWANIU O PRZYZNANIE PRAWA POMOCY PRZED SĄDEM ADMINISTRACYJNYM}

Poczynione wcześniej ustalenia umożliwiają przeanalizowanie kolejnych uwarunkowań niestandardowej sytuacji kuratora spadku. Wiążą się one przede wszystkim z koniecznością uwzględnienia szczególnego statusu prawnego samego kuratora spadku. Przede wszystkim należy bowiem pamiętać, że zadaniem kuratora spadku jest przeprowadzenie postępowania spadkowego bez uszczerbku dla nieznanych spadkobierców, co oznacza zabezpieczenie ich wszelkich praw związanych $\mathrm{z}$ nieobjętym spadkiem ${ }^{16}$. W praktyce kurator spadku jest ustanawiany do podejmowania czynności związanych z poszukiwaniem spadkobierców oraz do zarządzania majątkiem spadkowym pod nadzorem sądu ${ }^{17}$. Z tych względów w literaturze przyjmuje się, że kurator spadku jest kuratorem prawa materialnego ${ }^{18}$.

14 Z.R. Kmiecik, Glosa do postanowienia Sadu Najwyższego z 5 I 2001, III RN 45/00, „Państwo i Prawo” 2002, nr 10, s 107-112; E. Łętowska, O definicji prawa do sadu, „Państwo i Prawo” 2002, nr 12, s. 78; Z. Kmieciak, O definicji prawa do sądu raz jeszcze, „Państwo i Prawo” 2003, nr 3, s. 102.

15 Postanowienia referendarza sądowego WSA w Poznaniu z dnia: 3 lutego 2011 roku, sygn. akt II SA/Po 775/10, LEX nr 770959; 22 stycznia 2015 roku, sygn. akt III SA/Po 932/11, LEX nr 1644220.

16 Postanowienie referendarza sądowego WSA w Warszawie z dnia 18 lutego 2014 roku, sygn. akt I SA/Wa 18/14.

17 Zob. art. 667 § 1-2 ustawy z dnia 17 listopada 1964 roku Kodeks postępowania cywilnego (tekst jedn. Dz.U. z 2018 r., poz. 155, dalej: k.p.c.).

18 Postanowienie SN z dnia 26 listopada 2009 roku, sygn. akt I CZ 75/09, Orzecznictwo Sądu Najwyższego. Izba Cywilna — Zbiór Dodatkowy 2010, nr 3, poz. 83, LEX nr 558803; postanowienie SN z dnia 8 maja 2015 roku, sygn. akt III CZP 16/15, LEX nr 1749596; A. Łopuszyński, Kurator 
Elementem funkcji pełnionej przez kuratora prawa materialnego pozostaje również zapewnienie reprezentacji stronie $\mathrm{w}$ każdym postępowaniu procesowym ${ }^{19}$. W ramach pełnionej funkcji kurator spadku może zatem podejmować wszelkie czynności materialnoprawne oraz procesowe, aby zadbać o prawa i interesy spadkobierców, którzy nie mogą sami podejmować takich czynności ${ }^{20}$. W efekcie, pełniąc przede wszystkim funkcję procesową, kurator spadku może uczestniczyć w postępowaniu przed sądem administracyjnym. Ze względu na charakter sprawowanej kurateli nie będzie on jednak ograniczony wyłącznie do podejmowania czynności procesowych ${ }^{21}$.

\section{DWIE KONCEPCJE REPREZENTACJI NIEZNANYCH SPADKOBIERCÓW PRZEZ KURATORA SPADKU}

W przypadku kuratora spadku należy uwzględnić poglądy różnie postrzegające zakres umocowania kuratora spadku do działania w imieniu spadkobierców. Przyjęcie jednej z konstrukcji odnoszących się do reprezentacji nieznanych spadkobierców pozostaje kluczowe w ubieganiu się przez kuratora spadku o przyznanie prawa pomocy. W praktyce wywołuje bowiem poważne następstwa $\mathrm{w}$ prawidłowym wypełnieniu wniosku o przyznanie prawa pomocy, a w konsekwencji również ma znaczenie dla jego rozpoznania. W tym względzie powszechnie zaakceptowane jest stanowisko, że kurator spadku zawsze występuje w interesie spadkobierców. Według jednej z koncepcji, prezentowanej zarówno w literaturze ${ }^{22}$,jak

w postępowaniu przed sadem rejestrowym, „Monitor Prawniczy” 2006, nr 3, 132; M. Margoński, Kurator spadku..., s. 31 n, 60; P. Gorajewski, Kurator, likwidator i syndyk masy upadłości w postępowaniu sądowoadministracyjnym, [w:] Spótki jako strony w postępowaniu sądowoadministracyjnym. Materiały z seminarium szkoleniowego dla asystentów. Naczelny Sąd Administracyjny, Warszawa, dnia 27 listopada 2017 roku, „Materiały Szkoleniowe” 47, 2018, s. 7-8.

19 K. Korzan, Kurator w postępowaniu..., s. 28.

20 M. Margoński, Status prawny kuratora spadku. Glosa do uchwaty składu siedmiu sędziów Sądu Najwyższego z dnia 1 lutego 2011 roku (III CZP 78/10), „Polski Proces Cywilny” 2012, nr 1, s. $165-172$.

21 Postanowienie SN z dnia 20 marca 1991 roku, sygn. akt III CRN 70/91, LEX nr 110597. W przypadku kuratora procesowego sporne pozostaje skuteczne podejmowanie innych czynności prawnych — por. M. Rzewuska, M. Rzewuski, Ważność ugody zawartej przez kuratora procesowego ustanowionego dla strony, której miejsce pobytu nie jest znane - glosa - II CSK 261/07, „Monitor Prawniczy” 2009, nr 20, s. 1130-1132.

22 W. Broniewicz, W kwestii prawnego kuratora, „Palestra” 12, 1968, nr 6, s. 60 n.; M. Uliasz, Komentarz do art. 667 k.p.c., [w:] Kodeks postępowania cywilnego. Komentarz, Warszawa 2008, s. 964; S. Kalus, Komentarz do art. 178 Kodeksu rodzinnego i opiekuńczego, [w:] Kodeks rodzinny i opiekuńczy. Komentarz, red. K. Piasecki, Warszawa 2006, s. 927; A. Stempniak, Zarzad spadku nieobjętego w ujęciu przepisów KPC - cz. III, „Monitor Prawniczy” 2010, nr 20, s. 1126; B. Kordasiewicz, Przyjęcie i odrzucenie spadku, [w:] System Prawa Prywatnego, red. Z. Radwański, t. 10. Prawo spadkowe, red. B. Kordasiewcz, Warszawa 2015, s. 570; J. Gudowski, Komentarz do art. 667 
i w orzecznictwie ${ }^{23}$, kurator spadku jest uznawany za ,zastępcę pośredniego nieustalonych spadkobierców, który działa we własnym imieniu w obrocie prawnym jako strona, ale na rzecz spadkobierców”. Z uwagi na szczególne uwarunkowania kuratora spadku jest on niekiedy uważany za ,szczególnego rodzaju zastępcę pośredniego" 24 . Taki status kuratora spadku jako zastępcy pośredniego bywa łączony z takim samym statusem zarządcy nieruchomości z uwagi na odpowiednie stosowania przepisów o zarządzie nieruchomości do kurateli spadku ${ }^{25}$. W myśl tej koncepcji można by zatem przyjąć, że kurator spadku sprawuje tylko zarząd i nadzór nad określoną masą majątkową, a nie nad określoną osobą albo grupą osób $^{26}$. W istocie jednak kurator spadku przede wszystkim reprezentuje interesy nieznanych spadkobierców, które determinują jego funkcję. W tym względzie należy jednak zwrócić uwagę na szeroko pojmowaną „teorię zastępstwa” (niem. Vertretungstheorie), która nie przyznaje automatycznie kuratorowi spadku charakteru strony procesowej w ramach jego upoważnienia, tylko uznaje go za przedstawiciela (zastępcę) ustawowego ${ }^{27}$. Taka koncepcja nieco komplikuje postrzeganie pozycji kuratora spadku, który nie powinien być bezrefleksyjnie uznawany za stronę w rozumieniu procesowym, działającą we własnym imieniu oraz interesie, gdyż w istocie działa on na rzecz spadkobierców ${ }^{28}$. Co więcej, kurator spadku nie jest też

k.p.c., [w:] Kodeks postępowania cywilnego. Komentarz, t. 4. Postępowanie rozpoznawcze. Postępowanie zabezpieczajace, red. T. Ereciński, Warszawa 2016, s. 539-540; G. Wolak, Kurator spadku a postępowanie o zniesienie wspótwłasności, „Przegląd Prawno-Ekonomiczny” 2017, nr 2, s. 111; S. Lisowska-Krakowiak, Instytucje kuratorów a realizacja prawa do sądu w cywilnym postępowaniu rozpoznawczym, Warszawa 2018, s. 217-218; M. Pazdan, Przedstawicielstwo, [w:] System Prawa Prywatnego, red. Z. Radwański, t. 2. Prawo cywilne - część ogólna, red. Z. Radwański, A. Olejniczak, Warszawa 2019, s. 598, 612.

${ }^{23}$ Uchwała SN z dnia 2 kwietnia 2008 roku, sygn. akt III CZP 12/08, Orzecznictwo Sądu Najwyższego Izba Cywilna 2009, nr 6, poz. 78, „Monitor Prawniczy” 2008, nr 6, s. 450; uchwała SN z dnia 1 lutego 2011 roku, sygn. akt III CZP 78/10, Orzecznictwo Sądu Najwyższego Izba Cywilna 2011, nr 6, poz. 61; wyrok SN z dnia 10 grudnia 2009 roku, sygn. akt III CSK 82/09, LEX nr 2221912; wyrok SN z dnia 5 kwietnia 1956 roku, sygn. akt III CR 566/56, Orzecznictwo Sądu Najwyższego Izba Cywilna i Karna 1956, nr 4, poz. 115; wyrok SA w Warszawie z dnia 12 kwietnia 2017 roku, sygn. akt I ACa 152/16, LEX nr 2317757; wyrok NSA z dnia 17 marca 2015 roku, sygn. Akt I FSK 2169/13; wyrok WSA w Krakowie z dnia 20 marca 2017 roku, sygn. akt I SA/Kr 105/17.

24 J.S. Piątowski, H. Witczak, A. Kawałko, Spadek. Ogólna problematyka dziedziczenia, [w:] System Prawa Prywatnego, red. Z. Radwański, t. 10. Prawo spadkowe, red. B Kordasiewcz, Warszawa 2015, s. 211.

25 Podobna konstrukcja jest prezentowana w stosunku do syndyka masy upadłościowej, który podejmując czynności dotyczące praw i obowiązków odnoszących się do mienia wchodzącego w skład masy upadłościowej, posiada legitymację do działania na rachunek podmiotu upadłego — por. wyrok SN z dnia 10 grudnia 2009 roku, sygn. akt III CSK 82/09, Lex Polonica nr 2221912; postanowienie NSA z dnia 12 maja 2016 roku, sygn. akt I OZ 454/16, LEX nr 2036332.

26 Wyrok SN z dnia 16 lutego 2012 roku, sygn. akt III CSK 159/11, LEX nr 1131126; wyrok SA w Warszawie z dnia 12 kwietnia 2017 roku, sygn. akt I ACa 152/16.

27 B. Wieczorek, Zivilprozessordnung und Nebengesetze, t. 1, cz. 1, Berlin 1957, s. 376.

28 K. Korzan, Kurator w postepowaniu ..., s. 28; K. Korzan, Koszty procesu ..., s. 29. 
stroną w rozumieniu materialnoprawnym, która reprezentuje własne interesy we własnym imieniu, gdyż również działa na rzecz spadkobierców. W konsekwencji pozycja prawna kuratora spadku w istocie pozostaje bardziej podobna do pozycji podmiotu, który nie będąc stroną stosunku materialnego prawnego (strony w rozumieniu materialnym) jednocześnie zgłasza swoje żądania ${ }^{29}$. Przyjęcie takiego poglądu dotyczącego ,zastępstwa pośredniego” w odniesieniu do kuratora spadku w postępowaniu sądowoadministracyjnym wiązałoby się z koniecznością zawarcia we wniosku o przyznanie prawa pomocy informacji dotyczących aktualnej sytuacji finansowej i osobistej samego kuratora spadku, który ma występować w obrocie prawnym jak strona działająca we własnym imieniu, ale na rzecz spadkobierców. Jednak w tej kwestii należy zwrócić uwagę, że przepisy dotyczące możliwości przyznania prawa pomocy, które zostały zawarte w oddziale 2 rozdziału 2 działu v P.p.s.a., odnoszą się jedynie do „strony”30. Podczas gdy kurator spadku, tak jak zostało już wspomniane, nie posiada automatycznie statusu strony każdego postępowania $^{31}$. Wprawdzie można by przyjąć, że występuje on w postępowaniu we własnym imieniu, ale nie jest uprawniony do ubiegania się o przyznanie prawa pomocy na własną rzecz tylko w odniesieniu do praw i obowiązków nieznanych spadkobierców. W żaden sposób taka przeszkoda nie powinna jednak ograniczać prawa kuratora spadku (w ramach reprezentacji nieznanych spadkobierców) do ubiegania się o przyznanie prawa pomocy w postępowaniu toczącym się przed sądem administracyjnym. Wykluczenie możliwości ubiegania się przez kuratora spadku o przyznanie prawa pomocy we własnym imieniu nie powinno ograniczać w szerszym zakresie prawa do sądu jednostek, które on reprezentuje. W tym przypadku nie można ograniczać prawa spadkobierców zmarłej strony postępowania, które zachowują takie uprawnienie z mocy Konstytucji RP ${ }^{32}$ oraz Europejskiej konwencji o ochronie praw człowieka i podstawowych wolności ${ }^{33}$. Kluczowa po-

29 Uchwała SN z dnia 2 kwietnia 2008 roku, sygn. akt III CZP 12/08,,Orzecznictwo Sądu Najwyższego Izba Cywilna” 2009, nr 6, poz. 78, „Monitor Prawniczy” 2008, nr 6, s. 450.

${ }^{30} \mathrm{~W}$ znaczeniu procesowym pojęcie strony odnosi się do organu, którego działanie lub bezczynność stanowi przedmiot skargi, a także do jednostek, które występują w charakterze skarżących (art. 32 P.p.s.a.) albo w charakterze uczestników postępowania (art. 33 P.p.s.a. w związku $\mathrm{z}$ art.12 P.p.s.a.).

31 W. Broniewicz, Podstawienie procesowe, „Zeszyty Naukowe Uniwersytetu Łódzkiego, Nauki Humanistyczne-Społeczne” 1963, z. 31, s. 152.

32 Zob. art. 45 ust. 1 i art. 78 Konstytucji Rzeczypospolitej Polskiej z dnia 2 kwietnia 1997 roku (Dz.U. z 1997 r. Nr 78, poz. 483 ze zm.).

33 Zob. art. 6 Konwencji o ochronie praw człowieka i podstawowych wolności, sporządzona w Rzymie dnia 4 listopada 1950 roku, zmieniona następnie Protokołami nr 3, 5 i 8 oraz uzupełniona Protokołem nr 2 (Dz.U. z 1993 r. Nr 61, poz. 284). W orzecznictwie sądów administracyjnych prezentowany jest taki pogląd $\mathrm{w}$ kwestii prawa ubiegania się o przyznanie prawa pomocy przez kuratora dla osoby nieobecnej (kuratora absentis) — por. postanowienie referendarza sądowego WSA w Krakowie z dnia 19 listopada 2010 roku, sygn. akt III SA/Kr 88/10; postanowienie referendarza sądowego WSA w Krakowie z dnia 16 stycznia 2015 roku, sygn. akt III SA/Kr 1183/14. 
zostaje zatem druga $\mathrm{z}$ koncepcji prezentowanych zarówno $\mathrm{w}$ literaturze ${ }^{34}$, jak i orzecznictwie ${ }^{35}$, stanowiąca, że kurator spadku jest „zastępcą bezpośrednim (przedstawicielem ustawowym) nieustalonych spadkobierców, który działa w ich imieniu w obrocie prawnym". Przyjmuje się, że taki charakter kuratora spadku zagwarantuje efektywniejszy zarząd majątkiem spadkowym ${ }^{36}$. W tym przypadku status prawny kuratora spadku jest podobny do statusu prawnego kuratora ustanawianego dla nieobecnego (kuratora absentis), który jest przedstawicielem ustawowym reprezentowanego i podejmuje działania w interesie nieobecnego, co oznacza, że działa w jego imieniu, a także na jego rachunek ${ }^{37}$. Takie przedstawicielstwo polega na podejmowaniu działań w imieniu reprezentowanego, które

34 K. Korzan, Zastępstwo strony przez kuratora w postępowaniu cywilnym, „Nowe Prawo” 1964, nr 5, s. 504-505; K. Korzan, Kurator w postepowaniu..., s. 55; K. Korzan, Stanowisko prawne kuratora spadku, „Palestra” 11, 1967, nr 12, s. 20 n.; K. Korzan, Koszty procesu..., s. 29; K. Korzan, Glosa do wyroku z dnia 8 lipca 1969 roku (III CRN 220/69), „Nowe Prawo” 1971, nr 7-8, s. 1197-1199; J.S. Piątowski, Prawo spadkowe. Zarys wykładu, Państwowe Wydawnictwo Naukowe, Warszawa 1973, s. 78; K. Korzan, Stanowisko prawne syndyka masy upadtości i jego kwalifikacje, „Przegląd Prawa Handlowego” 1993, nr 8, s. 8-17; A. Matan, Kurator spadku jako zastępca procesowy strony w postępowaniu administracyjnym, „Roczniki Administracji i Prawa: Teoria i Praktyka" 2000, nr 1, s. 68; A. Pokora, Kilka uwag na temat relacji między syndykiem masy upadłościowej, a podmiotami zajmujacymi analogiczne stanowisko oraz zagadnienia pozycji prawnej zarządcy odrębnego majątku w postępowaniu upadłościowym, [w:] Wokót problematyki cywilnoprocesowej. Studium teoretycznoprawne. Ksiega pamiatkowa dla uczczenia pracy naukowej Profesora Kazimierza Korzana, red. A. Nowak, Katowice 2001, s. 218; M. Margoński, Kurator spadku, Warszawa 2009, s. 81; E. Cisowska-Sakrajda, Kurator w postępowaniu przed sadami administracyjnymi, [w:] Przeglad dyscyplin badawczych i pokrewnych nauce prawa i postepowania administracyjnego. Zjazd Katedr Prawa Administracyjnego i Postępowania Administracyjnego, red. S. Wrzosek et al., Lublin 2010, s. 194-195.

35 Uchwała SN z dnia 2 kwietnia 2008 roku, sygn. akt III CZP 12/08; wyrok SN z dnia 5 kwietnia 1956 roku, sygn. akt III Cr 566/56, „Orzecznictwo Sądu Najwyższego” 1956, nr 4, poz. 115; postanowienie WSA we Wrocławiu z dnia 12 grudnia 2013 roku, sygn. akt I SA/Wr 1462/10, LEX nr 2075562; postanowienie WSA w Warszawie z dnia 14 sierpnia 2014 roku, sygn. akt I SA/Wa 17/14, LEX nr 1541681.

36 M. Margoński, Status prawny kuratora spadku. Glosa do uchwaty składu siedmiu sędziów Sądu Najwyższego z dnia 1 lutego 2011 roku (III CZP 78/10), „Polski Proces Cywilny” 2012, nr 1, s. $165-172$.

37 Wyrok SN z dnia 23 maja 2003 roku, sygn. akt III CA 1/2003, LEX nr 1624828; wyrok WSA w Gorzowie Wlkp. z dnia 20 lutego 2008 roku, sygn. akt II SA/Go 213/06, LEX nr 459971; wyrok WSA w Warszawie z dnia 9 listopada 2006 roku, sygn. akt I SA/Wa 1370/06, LEX nr 320779. Taki zakres umocowania kuratora absentis jest również przypisywany w postępowaniu administracyjnym — por. A. Matan, Nieobecność strony w postępowaniu administracyjnym (problem zapewnienia właściwej reprezentacji), „Casus” 2002, nr 24, s. 8; K.A. Politowicz, Kurator dla osoby nieobecnej w postępowaniu administracyjnym - w ujęciu prawnoporównawczym, cz. 2. Charakter kurateli w postępowaniu administracyjnym i sadowoadministracyjnym, „Casus” 2012, nr 64, s. 53; J. Chmiel, Kurator dla osoby nieznanej z miejsca pobytu przed organami administracji publicznej i sądami administracyjnymi, „Casus” 2016, nr 81, s. 55; I. Jaworska, Przedstawiciel dla osoby nieobecnej w postępowaniu administracyjnym, „Zeszyty Naukowe Państwowej Wyższej Szkoły Zawodowej im. Witelona w Legnicy" 2017, nr 3, s. 137. 
zarazem wywierają skutki bezpośrednio dla zastąpionego, a więc i na jego rachu$n^{38}{ }^{38}$. Odnośnie do kuratora spadku wykonuje on czynności, które zabezpieczają i utrzymują masę spadkową w niepogorszonym stanie do momentu jej objęcia przez spadkobierców, ale cały czas pozostaje jedynie zarządcą majątku nieobjętego przez nieznanych spadkobierców ${ }^{39}$. W szczególności kurator spadku nie realizuje własnego interesu finansowego w ramach podejmowanych czynności, tylko reprezentuje interesy spadku${ }^{40}$. Nie stwarza to zatem konieczności podejmowania przez spadkobierców dodatkowych czynności prawnych zmierzających do „uzyskania praw nabytych przez kuratora spadku”41. W takiej sytuacji czynności prawne podejmowane również wobec kuratora spadku pozostają skuteczne wobec spadkobierców ${ }^{42}$. W praktyce również wywołują one bezpośrednio skutki prawne w każdej sferze prawnej odnoszonej do nieznanych spadkobierców. Także orzeczenia sądu administracyjnego wydane w sprawie zainicjowanej przez kuratora spadku pozostają skuteczne wobec spadkobierców, których on reprezentuje. Zasadniczo zatem to drugie stanowisko pozostaje bardziej adekwatne w wypadku wniosku o przyznanie prawa pomocy złożonego przez kuratora spadku. W większym stopniu wydaje się bowiem odpowiadać rzeczywistej funkcji, jaką pełni kurator spadku. W konsekwencji zasadny wydaje się pogląd, że kurator spadku odgrywa rolę zastępcy procesowego zmarłej strony postępowania sądowoadministracyjnego i powinien być traktowany tak samo jak zmarła strona postępowania (spadkodawca) w zakresie uprawnień procesowych ${ }^{43}$. Przyjęcie takiego stanowiska na swój sposób wpisuje się w funkcjonujący w literaturze pogląd, że kurator spad$\mathrm{ku}$, działając $\mathrm{w}$ obrocie prawnym $\mathrm{w}$ imieniu i na rzecz spadkobierców, w swojej istocie występuje w charakterze strony ${ }^{44}$.

38 Zob. art. 95 § 2 ustawy z dnia 23 kwietnia 1964 roku — Kodeks cywilny (tekst jedn. Dz.U. z 2017 r. poz. 459 ze zm.).

39 P. Pruś, [w:] Kodeks postępowania cywilnego. Komentarz, red. M. Manowska, Warszawa 2013, s. 1181.

40 A. Zieliński, Kodeks postępowania cywilnego. Komentarz, Warszawa 2011, s. 1094.

${ }^{41}$ K. Korzan, Kurator w postępowaniu..., s. 15; K. Korzan, Glosa do wyroku z dnia 8 lipca 1969 roku..., s. 1197-1198; M. Margoński, Status prawny kuratora spadku. Glosa do uchwaty składu siedmiu sędziów Sądu Najwyższego z dnia 1 lutego 2011 roku (III CZP 78/10), „Polski Proces Cywilny" 2012, nr 1, s. 165-172.

42 Wyrok SN z dnia 5 kwietnia 1956 roku, sygn. akt III CR 566/56.

43 Wyrok WSA W Warszawie z dnia 14 czerwca 2007 roku, sygn. akt IV SA/Wa 487/07, LEX nr 351333; H. Knysiak-Molczyk, Prawo do korzystania z pomocy i instytucji reprezentacji w postępowaniu administracyjnym, „Samorząd Terytorialny” 2003, nr 9, s. 42.

44 K. Korzan, Stanowisko prawne kuratora..., s. 20; K. Korzan, Glosa do postanowienia Sadu Najwyższego - Izba Cywilna z dnia 3 lutego 1970 r., II CZ 32/69, „Orzecznictwo Sądów Polskich i Komisji Arbitrażowych" 1970, nr 11, poz. 226. 


\section{KONSEKWENCJE ZASTOSOWANIA TEORETYCZNEJ KONSTRUKCJI REPREZENTACJI NIEZNANYCH SPADKOBIERCÓW W POSTĘPOWANIU O PRZYZNANIE PRAWA POMOCY}

Przyjęcie określonego sposobu reprezentacji interesów nieznanych spadkobierców przez kuratora spadku — z uwagi na jego specyficzny charakter prawny oraz specyficznie sprawowaną funkcję — umożliwia określenie warunków, jakie musi on spełnić, ubiegając się o pomoc ze strony Skarbu Państwa przed sądami administracyjnymi. Należy przede wszystkim zaznaczyć, że postępowania sądowe, w których uczestniczy kurator spadku, są tak rzadkie, że ustawodawca nie przewidział żadnych szczególnych zasad, które miałyby do niego zastosowanie. W szczególności nie przewidziano specjalnego formularza wniosku o prawo pomocy, na którym kurator spadku miałby się ubiegać o prawo pomocy. W rezultacie powinien on skorzystać z formularza przewidzianego dla osób fizycznych (PPF), który powinien zostać odpowiednio zaadaptowany do okoliczności sprawy. Sytuacja pozostaje jednak o tyle specyficzna, że kurator spadku we wniosku o przyznanie prawa pomocy nie powinien wskazywać informacji dotyczących jego własnej sytuacji finansowej, gdyż nie reprezentuje on swoich interesów, tylko powinien podać informacje dotyczące aktualnego stanu zarządzanego majątku spadkowego (aktualnego stanu masy spadkowej) ${ }^{45}$. Tego rodzaju informacje mogą zostać zaczerpnięte z przeprowadzonego z inicjatywy sądu spadku spisu inwentarza majątku spadkowego, w którym powinno zostać określone, jakie pasywa i aktywa wchodzą w skład spadku ${ }^{46}$. Natomiast informacja na temat dochodów, jakie przynosi zarządzana masa spadkowa, mogą zostać zaczerpnięte ze sprawozdania ze sprawowanej kurateli, do którego składania kurator spadku jest zobowiązany względem sądu spadku $^{47}$. Takie wskazanie we wniosku o prawo pomocy informacji, które dotyczą majątku osób trzecich, pozostaje zgodne z poglądem utrwalonym w orzecznictwie,

45 Postanowienie NSA z dnia 23 kwietnia 2015 roku, sygn. akt II OZ 336/15; postanowienie referendarza sądowego WSA w Poznaniu z dnia 3 lutego 2011 roku, sygn. akt II SA/Po 775/10; postanowienie referendarza sądowego WSA w Gorzowie Wlkp. z dnia 13 października 2014 roku, sygn. akt I SA/Go 511/14, LEX nr 1521408; postanowienie referendarza sądowego WSA w Warszawie z dnia 18 listopada 2014 roku, sygn. akt VII SA/Wa 2669/13; postanowienie referendarza sądowego WSA w Poznaniu z dnia 22 stycznia 2015 roku, sygn. akt III SA/Po 932/11; postanowienie referendarza sądowego WSA w Gdańsku z dnia 11 sierpnia 2015 roku, sygn. akt III SA/ Gd 1027/14; postanowienie referendarza sądowego WSA w Gdańsku z dnia 30 czerwca 2017 roku, sygn. akt II SA/Gd 124/17.

46 A. Stempniak, Spis inwentarza - wybrane aspekty postępowania (cz. I), „Monitor Prawniczy" 2012, nr 5, s. 246-257; A. Stempniak, Spis inwentarza - wybrane aspekty postepowania (cz. II), „Monitor Prawniczy” 2012, nr 6, s. 295-305.

47 Zgodnie z art. $937 \S 1 \mathrm{w}$ związku z art. 667 § 2 zdanie drugie k.p.c. sprawozdanie ze sprawowanej kurateli oprócz czynności związanych z wyjaśnieniem, kto jest spadkobiercą, obejmuje również czynności związane z zarządem majątkiem spadkiem. 
umożliwiającym złożenie wniosku o przyznanie prawa pomocy na urzędowym formularzu, wypełnionym i podpisanym przez pełnomocnika strony ${ }^{48}$.

\title{
PODSUMOWANIE
}

Kurator spadku może wszcząć postępowanie sądowoadministracyjne, gdy wymaga tego interes nieznanych spadkobierców (na przykład ze względu na konieczność ustalenia zobowiązania podatkowego wchodzącego w skład masy spadkowej). W przypadku wniesienia skargi do sądu administracyjnego przez kuratora spadku może on ubiegać się o zwolnienie od kosztów sądowych, gdyż nie został expressis verbis zwolniony od ich ponoszenia z mocy ustawy. Kurator spadku może również ubiegać się o ustanowienie pełnomocnika z urzędu, ze względu na zapewnienie prawa do sądu, zwłaszcza gdy profesjonalny pełnomocnik jest konieczny do sporządzenia środka odwoławczego (skargi kasacyjnej lub zażalenia). Nie zawsze bowiem funkcję kuratora pełni profesjonalny pełnomocnik (adwokat, radca prawny, doradca podatkowy), który może złożyć taki środek odwoławczy, reprezentując interesy nieznanych spadkobierców w ramach zarządu nieobjętym spadkiem ${ }^{49}$. W przypadku złożenia wniosku przyznanie prawa pomocy przez kuratora spadku należy również uwzględniać, że reprezentuje on interesy spadku, a więc miarodajne w kwestii uwzględnienia jego żądania będą informacje dotyczące masy spadkowej.

\section{REPRESENTATION OF UNKNOWN HEIRS BEFORE THE ADMINISTRATIVE COURT — SELECTED ISSUES OF THE RIGHT OF ASSISTANCE}

\begin{abstract}
Summary
The guardian of inheritance may initiate proceedings before an administrative court when the interests of unknown heirs so require (e.g. due to the need to determine the tax liability included in the estate). In the case of lodging a complaint to the administrative court by the guardian, he may apply for exemption from court costs because he has not been relieved expressis verbis from incurring them under the law. The guardian of the inheritance may also apply for the appointment of an public attorney because of the right to court, especially when a professional representative is required to draft an appeal. Not always the guardian is a professional attorney (advocate, legal counselor, tax advisor) who can submit such a remedy by representing the interests of unknown heirs within. In the case of submitting the application with demand of granting the right of assistance it

48 Uchwała NSA z dnia 20 maja 2010 roku, sygn. akt I OPS 11/09, Orzecznictwo Naczelnego Sądu Administracyjnego i Wojewódzkich Sądów Administracyjnych 2010, nr 4, poz. 54.

49 Postanowienie referendarza sądowego WSA w Poznaniu z dnia 22 stycznia 2015 roku, sygn. akt III SA/Po 932/11.
\end{abstract}


should have been taken into account that the guardian represents the interests of the inheritance. In consequence, the application should present actual information about the inheritance.

Keywords: guardian of inheritance, right of assistance, proceedings before administrative courts, costs of proceedings

\section{BIBLIOGRAFIA}

Behrman H., Jakiej kategorii kuratorów przystuguje uwolnienie od kosztów sądowych na zasadzie art. 3 p. 2 przep. o koszt. sqdowych?, „Nowy Proces Cywilny” 1933, nr 13.

Błystak L., Kazek M., Koszty postępowania sądowoadministracyjnego. Komentarz, Warszawa 2015.

Broniewicz W., Podstawienie procesowe, „Zeszyty Naukowe Uniwersytetu Łódzkiego, Nauki Humanistyczne-Społeczne" 1963, z. 31.

Broniewicz W., W kwestii prawnego kuratora, „Palestra” 12, 1968, nr 6.

Chmiel J., Kurator dla osoby nieznanej z miejsca pobytu przed organami administracji publicznej i sadami administracyjnymi, „Casus” 2016, nr 81.

Cisowska-Sakrajda E., Kurator w postepowaniu przed sadami administracyjnymi, [w:] Przeglad dyscyplin badawczych i pokrewnych nauce prawa i postępowania administracyjnego. Zjazd Katedr Prawa Administracyjnego i Postępowania Administracyjnego, red. S. Wrzosek et al., Lublin 2010.

Gorajewski P., Kurator, likwidator i syndyk masy upadłości w postępowaniu sq̨dowoadministracyjnym, [w:] Spótki jako strony w postepowaniu sądowoadministracyjnym. Materiały z seminarium szkoleniowego dla asystentów. Naczelny Sąd Administracyjny, Warszawa, dnia 27 listopada 2017 roku, „Materiały Szkoleniowe” 47, 2018.

Grzymisławska-Cybulska M., Prawo pomocy w postępowaniu sadowoadministracyjnym jako element realizacji prawa do sadu, Warszawa 2013.

Gudowski J., Komentarz do art. 667 k.p.c., [w:] Kodeks postępowania cywilnego. Komentarz. Tom 4. Postępowanie rozpoznawcze. Postępowanie zabezpieczające, red. T. Ereciński, Warszawa 2016.

Jagielska M., Jagielski J., Gołaszewski P., [w:] Prawo o postępowaniu przed sq̨dami administracyjnymi. Komentarz, red. R. Hauser, M. Wierzbowski, Warszawa 2013.

Jaworska I., Przedstawiciel dla osoby nieobecnej w postępowaniu administracyjnym, ,Zeszyty Naukowe Państwowej Wyższej Szkoły Zawodowej im. Witelona w Legnicy” 2017, nr 3.

Kalus S., Komentarz do art. 178 Kodeksu rodzinnego i opiekuńczego, [w:] Kodeks rodzinny i opiekuńczy. Komentarz, red. K. Piasecki, Warszawa 2006.

Kmieciak Z., O definicji prawa do sądu raz jeszcze, „Państwo i Prawo” 2003, nr 3.

Kmiecik Z.R., Glosa do postanowienia Sądu Najwyższego z 5 I 2001, III RN 45/00, „Państwo i Prawo" $2002 \mathrm{nr} 10$.

Knysiak-Molczyk H., Prawo do korzystania z pomocy i instytucji reprezentacji w postępowaniu administracyjnym, „Samorząd Terytorialny” 2003, nr 9.

Kordasiewicz B., Przyjęcie i odrzucenie spadku, [w:] System Prawa Prywatnego, Z. Radwański, t. 10. Prawo spadkowe, red. B. Kordasiewcz, Warszawa 2015.

Korzan K., Glosa do postanowienia Sądu Najwyższego - Izba Cywilna z dnia 3 lutego 1970 r., II CZ 32/69, Orzecznictwo Sądów Polskich i Komisji Arbitrażowych 1970, nr 11, poz. 226.

Korzan K., Glosa do wyroku z dnia 8 lipca 1969 roku (III CRN 220/69), „Nowe Prawo” 1971, nr 7-8.

Korzan K., Koszty postępowania cywilnego a nakłady państwa na utrzymanie wymiaru sprawiedliwości, Gdańsk 1992.

Korzan K., Koszty procesu z udziałem kuratora, „Palestra” 12, 1968, nr 2.

Korzan K., Kurator w postępowaniu cywilnym, Warszawa 1966. 
Korzan K., Stanowisko prawne kuratora spadku, „Palestra” 11, 1967, nr 12.

Korzan K., Stanowisko prawne syndyka masy upadtości i jego kwalifikacje, „Przegląd Prawa Handlowego" 1993, nr 8.

Korzan K., Zastępstwo strony przez kuratora w postepowaniu cywilnym, „Nowe Prawo” 1964, nr 5.

Kowalczuk-Szymańska M., Brak zwolnienia kuratora spadku od kosztów sądowych, „Monitor Prawniczy" 2010, nr 23 (bezpłatny dodatek).

Lisowska-Krakowiak S., Instytucje kuratorów a realizacja prawa do sąu w cywilnym postępowaniu rozpoznawczym, Warszawa 2018.

Łętowska E., O definicji prawa do sądu, „Państwo i Prawo” 2002, nr 12.

Łopuszyński A., Kurator w postępowaniu przed sądem rejestrowym, „Monitor Prawniczy” 2006, nr 3.

Margoński M., Kurator spadku, Warszawa 2009.

Margoński M., Status prawny kuratora spadku. Glosa do uchwały składu siedmiu sędziów Sądu Najwyższego z dnia 1 lutego 2011 roku (III CZP 78/10), „Polski Proces Cywilny” 2012.

Matan A., Kurator spadku jako zastępca procesowy strony $w$ postępowaniu administracyjnym, „Roczniki Administracji i Prawa: Teoria i Praktyka” 2000, nr 1.

Matan A., Nieobecność strony w postępowaniu administracyjnym (problem zapewnienia właściwej reprezentacji), „Casus” 2002, nr 24.

Niemiec T.M., Kurator spadku — zwolnienie z kosztów sądowych, „Monitor Prawniczy” 2011, nr 22.

Pazdan M., Przedstawicielstwo, [w:] System Prawa Prywatnego, red. Z. Radwański, t. 2. Prawo cywilne - część ogólna, red. Z. Radwański, A. Olejniczak, Warszawa 2019.

Piątowski J.S., [w:] System prawa cywilnego, t. 4. Prawo spadkowe, red. J.S. Piątowski, Wrocław, 1986.

Piątowski J.S., Prawo spadkowe. Zarys wyktadu, Warszawa 1973.

Piątowski J.S., Witczak H., Kawałko A., Spadek. Ogólna problematyka dziedziczenia, [w:] System Prawa Prywatnego, red. Z. Radwański, t. 10. Prawo spadkowe, red. B. Kordasiewcz, Warszawa 2015.

Pokora A., Kilka uwag na temat relacji między syndykiem masy upadłościowej a podmiotami zajmujacymi analogiczne stanowisko oraz zagadnienia pozycji prawnej zarzadcy odrębnego majatku w postepowaniu upadłościowym, [w:] Wokót problematyki cywilnoprocesowej. Studium teoretycznoprawne. Ksiega pamiątkowa dla uczczenia pracy naukowej Profesora Kazimierza Korzana, red. A. Nowak, Katowice 2001.

Politowicz K.A., Kurator dla osoby nieobecnej w postepowaniu administracyjnym - w ujęciu prawnoporównawczym, cz. 2. Charakter kurateli w postępowaniu administracyjnym i sądowoadministracyjnym, „Casus” 2012, nr 64.

Pruś P., [w:] Kodeks postępowania cywilnego. Komentarz, red. M. Manowska, Warszawa 2013.

Rzewuska M., Rzewuski M., Ważność ugody zawartej przez kuratora procesowego ustanowionego dla strony, której miejsce pobytu nie jest znane - glosa - II CSK 261/07, „Monitor Prawniczy” 2009, nr 20.

Stempniak A., Spis inwentarza - wybrane aspekty postepowania (cz. I), „Monitor Prawniczy” 2012, $\mathrm{nr} 5$.

Stempniak A., Spis inwentarza - wybrane aspekty postępowania (cz. II), „Monitor Prawniczy” 2012, nr 6.

Stempniak A., Zarząd spadku nieobjętego w ujęciu przepisów KPC - cz. III, „Monitor Prawniczy" 2010, nr 20.

Talaga R., Obowiazek ponoszenia kosztów sądowych przez kuratora spadku w postępowaniu przed sądami administracyjnymi, „Przegląd Sądowy” 2018, nr 4.

Uliasz M., Komentarz do art. 667 k.p.c., [w:] Kodeks postępowania cywilnego. Komentarz, Warszawa 2008.

Wieczorek B., Zivilprozessordnung und Nebengesetze, t. 1, cz. 1, Berlin 1957. 
Wolak G., Kurator spadku a postępowanie o zniesienie wspótwłasności, „Przegląd Prawno-Ekonomiczny" 2017, nr 2.

Zieliński A., Kodeks postępowania cywilnego. Komentarz, Warszawa 2011.

\section{AKTY PRAWNE}

Konstytucja Rzeczypospolitej Polskiej z dnia 2 kwietnia 1997 roku (Dz.U. 1997 r. Nr 78, poz. 483 ze zm.).

Konwencja o ochronie praw człowieka i podstawowych wolności, sporządzona w Rzymie dnia 4 listopada 1950 roku, zmieniona następnie Protokołami nr 3, 5 i 8 oraz uzupełniona Protokołem nr 2 (Dz.U. z 1993 r. Nr 61, poz. 284).

Ustawa z dnia 30 grudnia 1950 roku Przepisy o kosztach sądowych w sprawach cywilnych (tekst jedn. Dz.U. z 1961 r. Nr 10, poz. 57 ze zm.).

Ustawa z dnia 13 czerwca 1967 roku o kosztach sądowych w sprawach cywilnych (tekst jedn. Dz.U. z 2002 r. Nr 9, poz. 88).

Ustawa z dnia 23 kwietnia 1964 roku Kodeks cywilny (tekst jedn. Dz.U. z 2017 r. poz. 459 ze zm.).

Ustawa z dnia 17 listopada 1964 roku Kodeks postępowania cywilnego (tekst jedn. Dz. U. z 2018 r. poz. 155).

Ustawa z dnia 30 sierpnia 2002 roku Prawo o postępowaniu przed sądami administracyjnymi (tekst jedn. Dz.U. z 2018 r. poz. 1302 ze zm.)

Ustawa z dnia 17 czerwca 2004 roku o skardze na naruszenie prawa strony do rozpoznania sprawy w postępowaniu przygotowawczym prowadzonym lub nadzorowanym przez prokuratora i postępowaniu sądowym bez nieuzasadnionej zwłoki (tekst jedn. Dz.U. Nr 179, poz. 1843 ze zm.).

\section{ORZECZNICTWO}

Postanowienie NSA z dnia 9 października 2009 roku, sygn. akt I OPP 52/09, Orzecznictwo Naczelnego Sądu Administracyjnego i Wojewódzkich Sądów Administracyjnych 2010, nr 6, poz. 101, Orzecznictwo Sądów Polskich 2010, nr 7, poz. 72, LEX nr 653395.

Postanowienie NSA z dnia 17 marca 2010 roku, sygn. akt I OZ 187/10, LEX nr 606389.

Postanowienie NSA z dnia 20 stycznia 2015 roku, sygn. akt II OZ 8/15, LEX nr 1628856.

Postanowienie NSA z dnia 18 lutego 2015 roku, sygn. akt I OZ 112/15, LEX nr 1772012.

Postanowienie NSA z dnia 23 kwietnia 2015 roku, sygn. akt II OZ 336/15, LEX nr 1956722.

Postanowienie NSA z dnia 12 maja 2016 roku, sygn. akt I OZ 454/16, LEX nr 2036332.

Postanowienie referendarza sądowego WSA w Gdańsku z dnia 11 sierpnia 2015 roku, sygn. akt III SA/Gd 1027/14, LEX nr 1776869.

Postanowienie referendarza sądowego WSA w Gdańsku z dnia 30 czerwca 2017 roku, sygn. akt II SA/Gd 124/17, LEX nr 2311408.

Postanowienie referendarza sądowego WSA w Gorzowie Wlkp. z dnia 13 października 2014 roku, sygn. akt I SA/Go 511/14, LEX nr 1521408.

Postanowienie referendarza sądowego WSA w Krakowie z dnia 19 listopada 2010 roku, sygn. akt III SA/Kr 88/10, LEX nr 776457.

Postanowienie referendarza sądowego WSA w Krakowie z dnia 16 stycznia 2015 roku, sygn. akt III SA/Kr 1183/14, LEX nr 1625613.

Postanowienie referendarza sądowego WSA w Krakowie z dnia 4 grudnia 2015 roku, sygn. akt II SA/Kr 1357/15, LEX nr 1939285.

Postanowienie referendarza sądowego WSA w Opolu z dnia 20 maja 2009 roku, sygn. akt II SA/Op 70/09, LEX nr 635211. 
Postanowienie referendarza sądowego WSA w Poznaniu z dnia 3 lutego 2011 roku, sygn. akt II SA/Po 775/10, LEX nr 770959.

Postanowienie referendarza sądowego WSA w Poznaniu z dnia 22 stycznia 2015 roku, sygn. akt III SA/Po 932/11, LEX nr 1644220.

Postanowienie referendarza sądowego WSA w Warszawie z dnia 15 stycznia 2013 roku, sygn. akt I SA/Wa 1234/12, LEX nr 1283290.

Postanowienie referendarza sądowego WSA w Warszawie z dnia 18 lutego 2014 roku, sygn. akt I SA/Wa 18/14, LEX nr 1579195.

Postanowienie referendarza sądowego WSA w Warszawie z dnia 18 listopada 2014 roku, sygn. akt VII SA/Wa 2669/13, LEX nr 1594899.

Postanowienie referendarza sądowego WSA w Warszawie z dnia 18 listopada 2015 roku, sygn. akt I SA/Wa 1893/15, LEX nr 1961491.

Postanowienie SN z dnia 20 marca 1991 roku, sygn. akt III CRN 70/91, LEX nr 110597.

Postanowienie SN z dnia 26 listopada 2009 roku, sygn. akt I CZ 75/09, Orzecznictwo Sądu Najwyższego. Izba Cywilna — Zbiór Dodatkowy 2010, nr 3, poz. 83, LEX nr 558803.

Postanowienie SN z dnia 8 maja 2015 roku, sygn. akt III CZP 16/15, LEX nr 1749596.

Postanowienie WSA w Gdańsku z dnia 18 marca 2015 roku, sygn. akt II SA/Gd 479/14, LEX nr 1655034.

Postanowienie WSA w Gdańsku z dnia 28 maja 2015 roku, sygn. akt II SA/Gd 479/14, LEX nr 1760132.

Postanowienie WSA w Warszawie z dnia 14 sierpnia 2014 roku, sygn. akt I SA/Wa 17/14, LEX nr 1541681.

Postanowienie WSA we Wrocławiu z dnia 12 grudnia 2013 roku, sygn. akt I SA/Wr 1462/10, LEX nr 2075562.

Uchwała SN z dnia 2 kwietnia 2008 roku, sygn. akt III CZP 12/08, Orzecznictwo Sądu Najwyższego Izba Cywilna 2009, nr 6, poz. 78, „Monitor Prawniczy” 2008, nr 6, s. 450.

Uchwała SN z dnia 1 lutego 2011 roku, sygn. akt III CZP 78/10, Orzecznictwo Sądu Najwyższego Izba Cywilna 2011, nr 6, poz. 61.

Uchwała NSA z dnia 20 maja 2010 roku, sygn. akt I OPS 11/09, Orzecznictwo Naczelnego Sądu Administracyjnego i Wojewódzkich Sądów Administracyjnych 2010, nr 4, poz. 54.

Wyrok NSA z dnia 17 marca 2015 roku, sygn. akt I FSK 2169/13.

Wyrok SA w Warszawie z dnia 12 kwietnia 2017 roku, sygn. akt I ACa 152/16, LEX nr 2317757.

Wyrok SN z dnia 5 kwietnia 1956 roku, sygn. akt III CR 566/56, Orzecznictwo Sądu Najwyższego Izba Cywilna i Karna 1956, nr 4, poz. 115.

Wyrok SN z dnia 23 maja 2003 roku, sygn. akt III CA 1/2003, Lex nr 1624828.

Wyrok SN z dnia 10 grudnia 2009 roku, sygn. akt III CSK 82/09, Lex nr 2221912.

Wyrok SN z dnia 16 lutego 2012 roku, sygn. akt III CSK 159/11, LEX nr 1131126.

Wyrok WSA w Gorzowie Wlkp. z dnia 20 lutego 2008 roku, sygn. akt II SA/Go 213/06, LEX nr 459971.

Wyrok WSA w Krakowie z dnia 20 marca 2017 roku, sygn. akt I SA/Kr 105/17.

Wyrok WSA w Warszawie z dnia 9 listopada 2006 roku, sygn. akt I SA/Wa 1370/06 LEX nr 320779. Wyrok WSA w Warszawie z dnia 14 czerwca 2007 roku, sygn. akt IV SA/Wa 487/07, LEX nr 351333. Wyrok WSA w Warszawie z dnia 7 listopada 2013 roku, sygn. akt VIII SA/Wa 564/13, LEX nr 1412272. 